\title{
Early post-operative serum albumin level predicts survival after curative nephrectomy for kidney cancer: a retrospective study
}

Yongquan Tang ${ }^{1+}$, Zhihong Liư ${ }^{2+}$, Jiayu Liang ${ }^{2}$, Ruochen Zhang ${ }^{3}$, Kan Wu², Zijun Zou ${ }^{4}$, Chuan Zhou ${ }^{2}$, Fuxun Zhang ${ }^{2}$ and Yiping $L^{2^{*}}$ (D)

\begin{abstract}
Background: Previous studies have shown that albumin-related systemic inflammation is associated with the longterm prognosis of cancer, but the clinical significance of an early ( $\leq 7$ days) post-operative serum albumin level has not been well-documented as a prognostic factor in patients with renal cell cancer.

Methods: We retrospectively included patients hospitalized for kidney cancer from January 2009 to May 2014. First, the receiver operating characteristic analysis was used to define the best cut-off of an early post-operative serum albumin level in determining the prognosis, from which survival analysis was performed.

Results: A total of 329 patients were included. The median duration of follow-up was 54.8 months. Patients with an early post-operative serum albumin level $<32 \mathrm{~g} / \mathrm{L}$ had a significantly shorter median recurrence-free survival (RFS; 49.1 versus 56.5 months, $P=0.001)$ and median overall survival (OS; 52.2 versus 57.0 months, $P=0.049$ ) than patients with an early post-operative serum albumin level $\geq 32 \mathrm{~g} / \mathrm{L}$. After adjusting for age, BMl, tumor stage, post-operative hemoglobin concentration, and pre-operative albumin, globulin, and hemoglobin levels, multivariate Cox regression showed that an early post-operative serum albumin level $<32 \mathrm{~g} / \mathrm{L}$ was an independent prognostic factor associated with a decreased RFS ( $\mathrm{HR}=3.60 ; 95 \% \mathrm{Cl}, 1.05-12.42$ [months], $P=0.042)$ and decreased OS (HR=9.95; 95\% Cl, 1.81-54. 80 [months], $P=0.008)$.
\end{abstract}

Conclusion: An early post-operative serum albumin level $<32 \mathrm{~g} / \mathrm{L}$ is an independent prognostic factor leading to an unfavorable RFS and OS. Prospective trials and further studies involving additional patients are warranted.

Keywords: Kidney cancer, Survival, Hypoalbuminemia, Radical resection

\section{Background}

Kidney cancer is one of the most common malignancies involving the urogenital system [1]. The most important treatment for kidney cancer is surgical resection, but post-operative recurrences are common, especially for stage II and above. A number of risk factors have been reported; however, prognostication remains difficult $[2,3]$.

\footnotetext{
* Correspondence: yiping_luuro@163.com

†Yongquan Tang and Zhihong Liu contributed equally to this work.

${ }^{2}$ Department of Urology, Institute of Urology, West China Hospital, Sichuan

University, Chengdu, China

Full list of author information is available at the end of the article
}

Notably, new prognostic factors have been described in recent years [4-7].

Several studies have reported that the early post-operative neutrophil-to-lymphocyte ratio may be a long-term prognostic factor for some cancers, including pancreatic, prostate, and bladder cancers [8-10]. This association may result from the potential anti-tumor effect of acute inflammation. Albumin is commonly used to evaluate nutritional status, but a recent study has shown that albumin is also involved in the inflammatory/stress reaction [11]. McMillan and colleagues [12] reported that the serum albumin level was positively correlated with the C-reactive protein level in 40 patients with lung or gastrointestinal cancer. Bozzetti

(C) The Author(s). 2018 Open Access This article is distributed under the terms of the Creative Commons Attribution 4.0 International License (http://creativecommons.org/licenses/by/4.0/), which permits unrestricted use, distribution, and 
and colleagues [13] first reported the phenomenon of frequent hypoalbuminemia status in the early period after extensive surgery. Based on our previous data, the serum albumin level was $<35 \mathrm{~g} / \mathrm{L}$ in $>50 \%$ of patients following curative nephrectomy $(P<0.05)$, then always recovered to the pre-operative level within 2 weeks. Some researchers have concluded that early post-operative hypoalbuminemia is associated with the pre-operative serum albumin level, age, and extent of surgery [12], while other studies have shown that post-operative hypoalbuminemia may lead to unfavorable short-term prognoses, such as acute kidney injury [13, 14], unbalanced substance metabolism [15-17], and surgical site infections [18, 19]. Such findings suggest that albumin has a role in immune-inflammatory reactions $[11,20]$.

Recent studies have revealed that albumin-related systemic inflammation is associated with the long-term prognosis in patients with advanced gastrointestinal cancer [11, 21, 22]. Cai and colleagues [23] found that hypoalbuminemia 3-5 weeks after initiation of tyrosine kinase inhibitors is independently associated with a significantly decreased progression-free survival (PFS) and overall survival (OS) in patients with advanced kidney cancer. Furthermore, when combined with the Memorial Sloan-Kettering Cancer Center (MSKCC) risk model, hypoalbuminemia improves the efficiency in predicting recurrence-free survival (RFS) and OS [23]. The current retrospective study determined the potential association between early ( $\leq 7$ days) post-operative hypoalbuminemia with long-term prognosis after resection of kidney cancer.

\section{Methods}

\section{Study population}

In this retrospective single-center study we reviewed the electronic medical records of inpatients with kidney cancer who were admitted to the Department of Urology at West China Hospital of Sichuan University (Sichuan, China) between January 2009 and May 2014. All of the patients underwent curative surgery. The inclusion criteria included the following: > 18 years of age; a pathologic diagnosis of kidney cancer; and negative surgical margins. Negative surgical margin was defined as macroscopic evidence on surgical report or microscopic evidence on histopathologic report. The exclusion criteria were as follows: incomplete resection; history of other life-threatening diseases within 5 years before or after surgery; adjuvant or neoadjuvant treatment; and distant metastasis, with the exception of the adrenal gland. The study conformed to the Declaration of Helsinki and was approved by the Ethics Committee of West China Hospital.

\section{Objectives}

We primarily assessed the prognostic value of early post-operative hypoalbuminemia with respect to RFS and
OS in the curative resection of kidney cancer. We then determined the optimal cut-off point of the early post-operative serum albumin level in predicting the prognosis of kidney cancer. RFS was defined as the date of surgery to the date of recurrence, and OS was measured from the date of surgery to the date of death. For patients without a recurrence or who did not die, survival was censored at the date of the last follow-up evaluation. To distinguish confounding factors, subgroup analyses were performed.

\section{Data collection}

All data were obtained from medical records. The follow-up project adhered to the National Comprehensive Cancer Network (NCCN) clinical practice guidelines for kidney cancer [24]. Data were collected by two welltrained researchers. Any discrepancies in data interpretation were resolved by consensus of all authors. The data collected included demographic characteristics, date and type of surgery, clinical-pathologic TNM stage at the time of surgery, histopathologic characteristics, and date of recurrence and/or death if available or date of the last follow-up. TNM stage referred to the tumor size (T), local lymph node involvement $(\mathrm{N})$, and remote metastasis $(\mathrm{M})$, and was assessed according to imaging studies, surgical records, and histopathologic reports. TNM stage and anatomic stage/prognostic groups were also guided by the 2018 NCCN guidelines for kidney cancer [24]. Cancer recurrence was defined as unequivocal radiologic or biopsy evidence of emerging local or distant tumor lesions. In addition, we collated serum albumin, globulin, and hemoglobin data obtained pre- and post-operatively.

\section{Statistics}

All statistical analyses were carried out using Stata 14.0 (Stata Corp, College Station, TX, USA). The receiver operating characteristic (ROC) curve analysis was performed to determine the optimal cut-off point for the post-operative serum albumin level for use in the post-operative prognosis. Based on the cut-off point, we divided the patients into two groups, then survival curves were created using the Kaplan-Meier method and compared using the log-rank test. Gender, age, body mass index (BMI), stage, type of surgery, and pathologic pattern for both groups of patients were compared and tested one-by-one. Four-fold or $\mathrm{R} \times \mathrm{C}$ table data were analyzed with a chi-square test. The median of data with a non-normal distribution was designated as the average and analyzed with the Wilcoxon rank-sum test. The mean of data with a normal distribution was designated as the average and analyzed with a t-test [25]. A factor was entered into multivariate Cox regression analysis if a statistical difference existed in both groups of patients. The hazard ratio (HR) was adopted as the measurement. A $P$ value $<0.05$ indicated statistical significance. 


\section{Results}

\section{Patients and disease characteristics}

A total of 694 patients were available in the database; 329 patients met the inclusion criteria. Among the 329 patients, $64 \%$ were male and the median age at the time of surgery was 56 years (range, 22-84 years). The median duration of follow-up was 54.8 months (range, 5.2-96.4 months). The mean pre- and post-operative serum albumin levels were 42.2 and $34.1 \mathrm{~g} / \mathrm{L}$, respectively $(P=0.000)$. ROC curve analyses showed that the optimal postoperative serum albumin cut-off level was $32 \mathrm{~g} / \mathrm{L}$ (area under the curve $[\mathrm{AUC}]=0.71$ ) in predicting tumor recurrence (Fig. 1a) and $31 \mathrm{~g} / \mathrm{L}(\mathrm{AUC}=0.80)$ in predicting death (Fig. 1b). Thus, we used $32 \mathrm{~g} / \mathrm{L}$ as the cut-off point for grouping comparisons. A total of 99 patients had a serum albumin level $<32 \mathrm{~g} / \mathrm{L}$ and 230 patients had a serum albumin level $\geq 32 \mathrm{~g} / \mathrm{L}$. The patient characteristics and laboratory test results for both groups are presented in Table 1. Age, BMI, tumor stage, post-operative hemoglobin concentration, and pre-operative albumin, globulin, and hemoglobin levels were statistically different (Table 1 ).

\section{Survival analysis}

No patients were lost to follow-up. The mean duration of follow-up in both groups was similar [58.5 (albumin $<32 \mathrm{~g} / \mathrm{L}$ ) and 59.9 (albumin $\geq 32 \mathrm{~g} / \mathrm{L}$ ) months, respectively; $P>0.05$ ]. During follow-up, 30 patients (30.3\%) had tumor recurrences and 24 patients (24.2\%) did not survive in the group of patients with a post-operative serum albumin level $<32 \mathrm{~g} / \mathrm{L}$. Only 20 patients $(8.7 \%)$ had tumor recurrences and 8 patients $(3.5 \%)$ did not survive in the group of patients with a post-operative serum albumin level $\geq 32 \mathrm{~g} / \mathrm{L}$. The median RFS of patients with a post-operative serum albumin level $<32 \mathrm{~g} / \mathrm{L}$ was significantly less than patients with a post-operative serum albumin level $\geq 32 \mathrm{~g} / \mathrm{L}$ (49.1 and 56.5 months, respectively; $P=0.001$ ). The median OS of patients with a post-operative serum albumin level $<32 \mathrm{~g} / \mathrm{L}$ was also significantly less than patients with a post-operative serum albumin level $\geq 32 \mathrm{~g} / \mathrm{L}$ (52.2 and 57.0 months, respectively; $P=0.049$ ). The group survival curves are shown in Fig. 2. The log-rank test revealed that the differences in group survival curves was significant $(P=0.000)$ for RFS (Fig. 2a) and OS (Fig. 2b).

\section{Multivariate cox regression}

Based on difference testing, age, BMI, tumor stage, post-operative hemoglobin concentration, and pre-operative albumin, globulin, and hemoglobin levels were entered into multivariate Cox regression analysis. An early post-operative serum albumin level $<32 \mathrm{~g} / \mathrm{L}$ was shown to have an independent impact on the decreased RFS (HR $=3.60$; 95\% CI,1.05-12.42 [months]; $P=0.042)$ and OS (HR = 9.95; 95\% CI, 1.81-54.80 [months]; $P=0.008$ ). In addition, tumor stage was also an independent prognostic factor (Table 2). Therefore, subgroup analysis was performed based on tumor stage.

\section{Sub-group analysis of stages II and III kidney cancer}

The survival curves of patients grouped by tumor stage and relevant log-rank testing showed significant differences between stages I and II, and stages III and IV for RFS and OS, but not between stages II and III. Furthermore, after excluding patients with stages I and IV, the two groups had similar TNM stage distributions $(P=0.995)$. Survival analysis and log-rank testing showed that patients with a post-operative serum albumin level $<32 \mathrm{~g} / \mathrm{L}$ had a significantly decreased RFS $(P=0.036)$ and decreased OS $(P=0.012)$ compared to patients with a post-operative
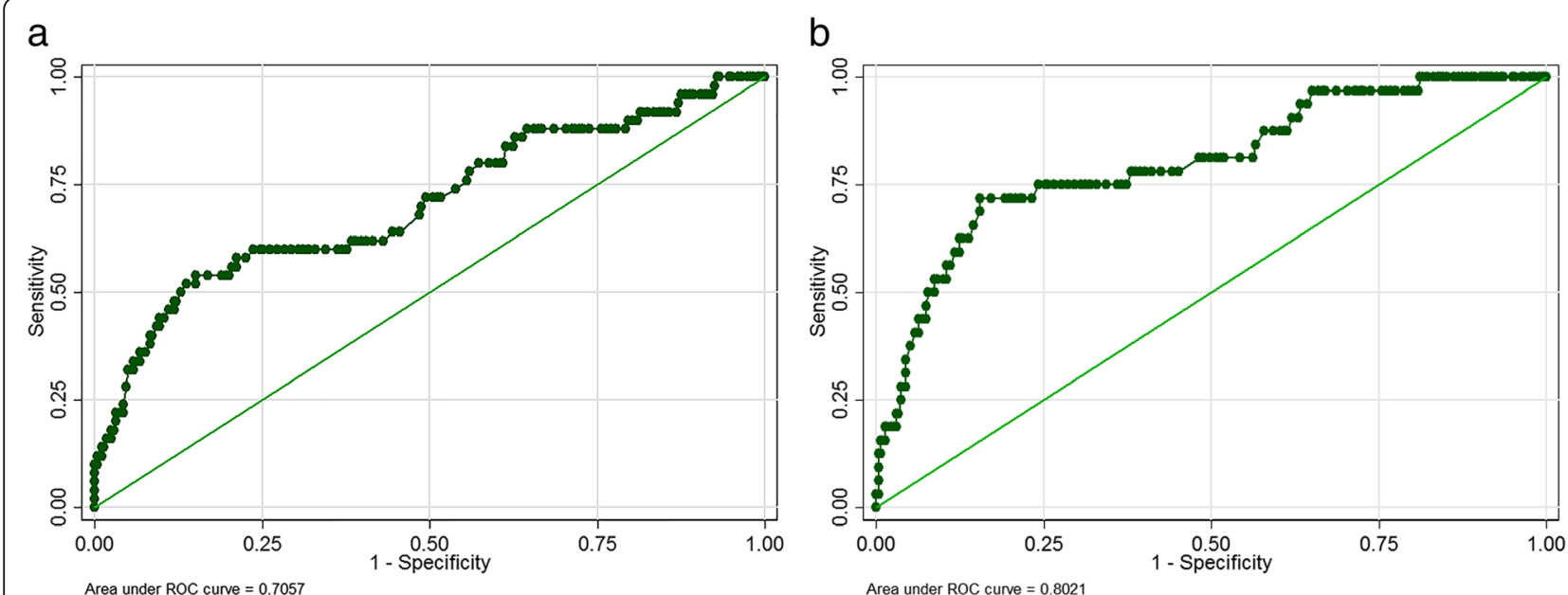

Fig. 1 Receiver operating characteristic (ROC) analysis to predict the best cutoff point of early post-operative serum albumin level in predicting recurrence (a) and death (b) and to calculate the area under the curve (AUC) 
Table 1 The baseline and clinic-pathologic characteristics of patients grouped by post-operative serum albumin level

\begin{tabular}{|c|c|c|c|}
\hline Variable & $\begin{array}{l}\text { Serum albumin } \\
<32 \mathrm{~g} / \mathrm{L}(n=99)\end{array}$ & $\begin{array}{l}\text { Serum albumin } \\
\geq 32 \mathrm{~g} / \mathrm{L}(n=230)\end{array}$ & $P$ \\
\hline Gender (\%) & & & 0.229 \\
\hline Male & $59(60)$ & $153(67)$ & \\
\hline Female & $40(40)$ & $77(33)$ & \\
\hline Age, y, median(range) & $63(22-82)$ & $53(24-84)$ & $0.000^{*}$ \\
\hline $\mathrm{BMl}, \mathrm{Kg} / \mathrm{m}^{2}$, mean $\pm \mathrm{SD}$ & $22.19 \pm 0.38$ & $23.84 \pm 0.37$ & $0.007^{*}$ \\
\hline $\begin{array}{l}\text { Symptom (none/local/ } \\
\text { system) }\end{array}$ & $(90 / 9 / 0)$ & $(211 / 19 / 0)$ & 0.805 \\
\hline ECOG-PS (0/1/2/3/4/5) & $88 / 11 / 0 / 0 / 0$ & 213/17/0/0/0 & 0.267 \\
\hline Stage (\%) & & & $0.000^{*}$ \\
\hline । & $46(46)$ & $192(83)$ & \\
\hline$\|$ & $18(18)$ & $13(6)$ & \\
\hline III & $29(29)$ & $21(9)$ & \\
\hline IV & $6(6)$ & $4(2)$ & \\
\hline Pathological type (\%) & & & 0.208 \\
\hline $\mathrm{cCRCC}$ & $88(89)$ & $214(93)$ & \\
\hline nccRCC & $11(11)$ & $16(7)$ & \\
\hline Type of surgery (\%) & & & 0.149 \\
\hline Radical nephrectomy & $73(74)$ & $151(66)$ & \\
\hline Partial nephrectomy & $26(26)$ & $79(34)$ & \\
\hline Fuhrman grade (\%) & & & 0.074 \\
\hline $1-2$ & $52(53)$ & $145(63)$ & \\
\hline $3-4$ & $47(47)$ & $85(37)$ & \\
\hline \multicolumn{4}{|l|}{ Preoperative, mean \pm SD } \\
\hline Alb, g/L & $39.42 \pm 0.43$ & $43.43 \pm 0.20$ & $0.000^{*}$ \\
\hline Glb, g/L & $29.20 \pm 0.58$ & $26.09 \pm 0.25$ & $0.000^{*}$ \\
\hline $\mathrm{Hgb}, \mathrm{g} / \mathrm{L}$ & $128.09 \pm 2.12$ & $138.24 \pm 1.06$ & $0.000^{*}$ \\
\hline \multicolumn{4}{|l|}{ Post-operative, mean \pm SD } \\
\hline Alb, g/L & $36.43 \pm 0.19$ & $28.77 \pm 0.34$ & $0.000^{*}$ \\
\hline Glb, g/L & $24.27 \pm 0.54$ & $24.16 \pm 0.24$ & 0.834 \\
\hline $\mathrm{Hgb}, \mathrm{g} / \mathrm{L}$ & $106.81 \pm 1.78$ & $123.71 \pm 1.15$ & $0.000^{*}$ \\
\hline
\end{tabular}

*Significant

$B M I$ body mass index, SD standard deviation, ECOP-PS Eastern Cooperative Oncology Group-performance status, cCRCC clear cell renal cell carcinoma, $n c c R C C$ non-clear cell renal cell carcinoma, Alb albumin, Glb globulin, $\mathrm{Hgb}$ hemoglobin

serum albumin level $\geq 32 \mathrm{~g} / \mathrm{L}$. Multivariate Cox regression analysis also showed that a early post-operative serum albumin level $<32 \mathrm{~g} / \mathrm{L}$ was an independent prognostic factor associated with decreased $\mathrm{RFS}(\mathrm{HR}=6.76 ; 95 \% \mathrm{CI}$, $1.07-$ 42.60; $P=0.042)$ and $\mathrm{OS}(\mathrm{HR}=26.92 ; 95 \% \mathrm{CI}, 1.52-477.30$; $P=0.025)$.

\section{Sub-group analysis based on other factors}

The histopathologic type of RCC is an important prognostic factor. Clear cell renal cell carcinoma (ccRCC) is the most common histopathologic type of kidney cancer.
There were $88(89 \%)$ and $214(93 \%)$ patients in the post-operative serum albumin levels $<32 \mathrm{~g} / \mathrm{L}$ and $\geq 32 \mathrm{~g} /$ $\mathrm{L}$, respectively. Survival analysis and log-rank testing showed that ccRCC patients with a post-operative serum albumin level $<32 \mathrm{~g} / \mathrm{L}$ had a significantly decreased RFS $(P=0.00)$ and decreased OS $(P=0.00)$ than patients with a post-operative serum albumin level $\geq 32 \mathrm{~g} / \mathrm{L}$.

The type of surgical procedure is another important factor determining prognosis in patients with kidney cancer, especially in patients who undergo partial or radical nephrectomies. Of 329 patients, 224 and 105 underwent radical and partial nephrectomies, respectively. Log-rank testing showed that patients who underwent radical nephrectomies with post-operative serum albumin levels $<32 \mathrm{~g} / \mathrm{L}$ had a significantly decreased RFS $(P=0.00)$ and decreased OS $(P=0.00)$ than patients with a post-operative serum albumin level $\geq 32 \mathrm{~g} / \mathrm{L}$. The RFS and OS among patients who underwent partial nephrectomies with a post-operative serum albumin level $<32 \mathrm{~g} / \mathrm{L}$ were not significantly different compared with patients who had a post-operative serum albumin $\geq 32 \mathrm{~g} / \mathrm{L}(P=0.15$ and 0.76 , respectively).

\section{Discussion}

Despite radical resection of kidney cancer, local recurrence or distant metastasis is commonplace [26-28]. With the exception of known prognostic factors, such as tumor stage, pathologic type, and type of surgical procedure, other potential prognostic factors warrant further elucidation $[2,3,29,30]$. In this retrospective study we report for the first time that an early post-operative serum albumin level is another long-term prognostic factor after radical resection of kidney cancer.

To prevent confounding factors as much as possible, we excluded patients who had incomplete tumor resections, other life-threatening diseases, and adjuvant and/ or neoadjuvant treatment. We excluded patients without serum protein and cell testing post-operatively, but it is unlikely that bias was introduced because no guidelines specify laboratory testing early after surgery without an indication. In our medical center, all radical surgeries for kidney cancer were performed by well-trained clinicians. To ensure a sufficient duration of follow-up, we only included patients who underwent surgery prior to May 2014. Approximately $42 \%$ of the enrolled patients had a duration of follow-up > 5 years and $94 \%$ of the enrolled patients had a duration of follow-up $>3$ years. The median duration of follow-up was nearly 5 years, and no patients were lost to follow-up.

The serum albumin level nearly returned to the pre-operative level in all patients who had repeat serum protein testing. A decrease in the serum albumin level may primarily result from exudation into the extravascular space and attenuation by perioperative bleeding and 

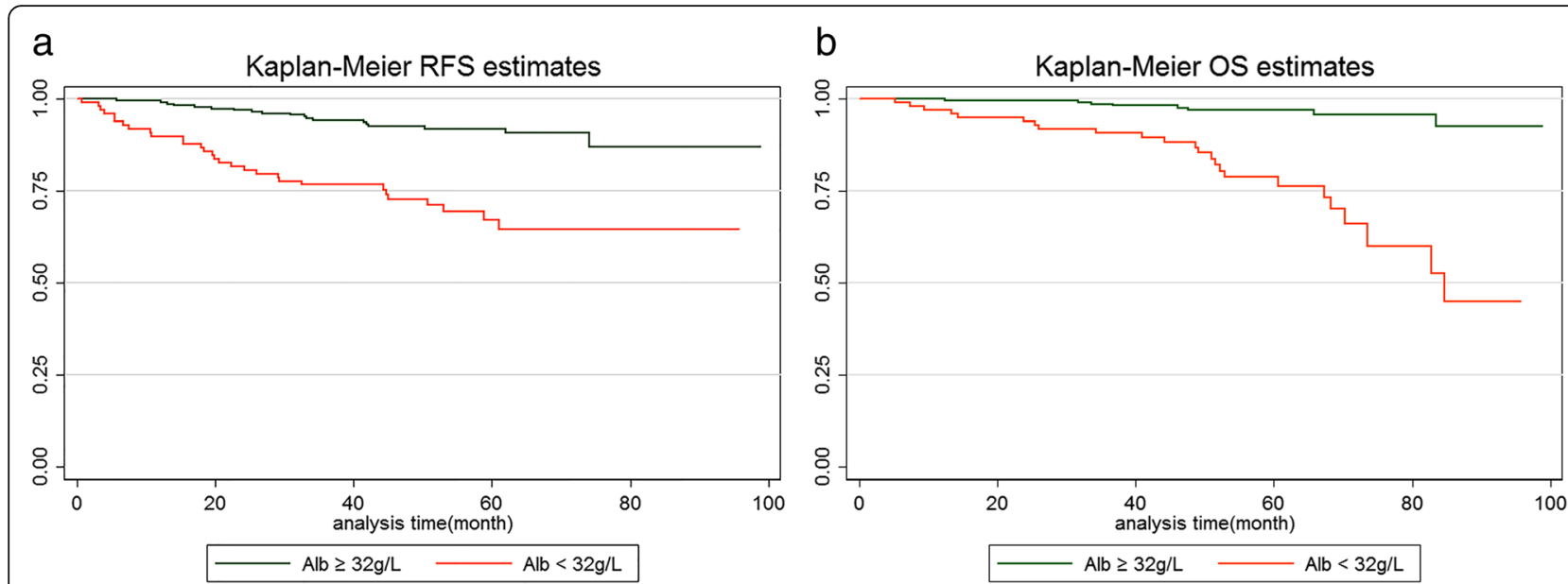

Fig. 2 Recurrence-free survival (RFS) (a) and overall survival (OS) (b) curves of patients with early post-operative serum albumin level $\geq 32 \mathrm{~g} / \mathrm{L}$ versus $<32 \mathrm{~g} / \mathrm{L}$

fluid transfusion [11, 31]. We found a significant decrease in the hemoglobin concentration early after surgery coincident with the decrease in serum albumin level; however, the post-operative serum albumin level was significantly decreased compared with the serum albumin level regulated by the hemoglobin concentration (34.1 versus 37.0 $\mathrm{g} / \mathrm{L}, P=0.00$ ), as follows: regulated serum albumin level $\div$ pre-operative albumin level $=$ post-operative hemoglobin concentration $\div$ pre-operative hemoglobin concentration. This decrease is regarded as extravascular exudation. When the post-operative serum albumin level and extravascular exudation were entered into Cox regression, the results showed that the post-operative serum albumin level had a close association with RFS $(\mathrm{HR}=0.85$, $P=0.000)$ and $\mathrm{OS}(\mathrm{HR}=0.82, P=0.000)$, unlike the

Table 2 Effect of early post-operative plasma albumin level on recurrence-free survival and overall survival in multivariate Cox regression analyses adjusted by gender, age, body mass index (BMI), tumor stage and some other laboratory indexes

\begin{tabular}{|c|c|c|c|c|c|c|}
\hline & \multicolumn{3}{|c|}{ Recurrence-free survival } & \multicolumn{3}{|c|}{ Overall survival } \\
\hline & $\mathrm{HR}$ & $95 \% \mathrm{Cl}$ & $P$ & $\mathrm{HR}$ & $95 \% \mathrm{Cl}$ & $P$ \\
\hline Age & 0.99 & $0.95-1.03$ & 0.573 & 1.00 & $0.96-1.04$ & 0.980 \\
\hline BMl & 0.99 & $0.88-1.12$ & 0.892 & 0.97 & $0.85-1.11$ & 0.684 \\
\hline Stage & 1.51 & $1.03-2.21$ & $0.034^{*}$ & 1.40 & $0.90-2.17$ & 0.136 \\
\hline \multicolumn{7}{|l|}{ Preoperative } \\
\hline Alb & 0.99 & $0.86-1.13$ & 0.866 & 0.99 & $0.83-1.18$ & 0.906 \\
\hline Glb & 1.09 & 0.99-1.19 & 0.055 & 1.08 & $0.99-1.19$ & 0.094 \\
\hline $\mathrm{Hgb}$ & 1.01 & $0.98-1.05$ & 0.420 & 1.00 & $0.96-1.05$ & 0.816 \\
\hline \multicolumn{7}{|l|}{ Post-operative } \\
\hline Alb $<32 \mathrm{~g} / \mathrm{L}$ & 3.60 & $1.05-12.42$ & $0.042^{*}$ & 9.95 & $1.81-54.80$ & $0.008^{*}$ \\
\hline $\mathrm{Hgb}$ & 1.00 & $0.97-1.04$ & 0.966 & 1.02 & $0.98-1.06$ & 0.418 \\
\hline
\end{tabular}

$H R$ hazard ratio, $\mathrm{Cl}$ confidence interval, Alb albumin, Glb globulin, Hgb hemoglobin association between extravascular exudation and RFS $(\mathrm{HR}=1.00, P=0.113)$ and $\mathrm{OS}(\mathrm{HR}=0.99, P=0.116)$.

For patients who underwent pathologic-complete resection of kidney cancer, we entered other universally-accepted prognostic factors before survival analysis, including gender, age, nutritional status (BMI), tumor stage, pathologic type, Fuhrman grade, and type of surgical procedure. Survival analysis showed that patients who had an early post-operative serum albumin level $<32 \mathrm{~g} / \mathrm{L}$ had a significantly decreased RFS and OS. Although patients in the group of patients with a lower post-operative albumin level were older, had a lower BMI, and more than stage III cancer and some laboratory values differed, multivariate Cox regression analysis admitted all of these factors, and the results showed that an early post-operative serum albumin level $<32 \mathrm{~g} / \mathrm{L}$ was an independent risk factor for a decreased RFS and OS. Positive results were obtained, even when patients were confined to stages II and III. In contrast, the log rank test did not reveal significant differences in RFS $(P=0.360)$ and OS $(P=0.814)$ between stages II and III in our patients. Sub-group analysis showed an association between the post-operative serum albumin level and long-term prognosis based on patients with ccRC who underwent radical nephrectomies versus partial nephrectomies; however, only 26 patients with a post-operative serum albumin level $<32 \mathrm{~g} / \mathrm{L}$ underwent partial nephrectomies. Indeed, the negative result may reflect the limited sample size.

Limited by the potential retrospective bias, the prognostic value of an early post-operative serum albumin level warrants more high-quality studies for further elucidation. Based on good category power (AUC $=0.71-0.8$ ), an early post-operative serum albumin level deserves more attention in predicting prognosis after radical resection of kidney cancer, especially combined with other prognostic factors. The mechanisms underlying the association remain unclear. In addition, whether or not transfusion of 
albumin leads to decreased tumor recurrence and death after resection of kidney cancer should be investigated.

\section{Conclusion}

In patients after curative resection of kidney cancer, this retrospective study revealed that an early post-operative serum albumin level $<32 \mathrm{~g} / \mathrm{L}$ is an independent risk factor associated with a decreased RFS and decreased OS. Prospective trials and further research in additional patients are needed.

\section{Abbreviations}

HR: Hazard Ratio; MSKCC: Memorial Sloan-Kettering Cancer Center; NCCN: National Comprehensive Cancer Network; OS: Overall Survival; RFS: Recurrence-free Survival; ROC: Receiver Operating Characteristic

\section{Acknowledgements}

Not applicable

\section{Funding}

This study is funded by the Department of Science and Technology of Sichuan Province, China (Grant No. 2017 SZ0123 and 2014JY0183) and 1.3.5 project for disciplines of excellence, West China Hospital, Sichuan University.

\section{Availability of data and materials}

The datasets used and/or analyzed during the current study are available from the corresponding author on reasonable request.

\section{Authors' contributions}

YT and ZL contributed primarily to the conception and design, acquisition of data and analysis, interpretation of data and manuscript drafting; $J$ and RZ participated in the design, acquisition of data and analysis, interpretation of data and manuscript drafting. KW and ZZ involved in collecting data and drafting the manuscript; CZ and FZ have been involved in data analysis and manuscript drafting; $Y L$ mainly contributed to interpretation of data, revision in critical content, supervision and final approval of the version to be published. All authors have read and approved the manuscript, and ensure that this is the case.

\section{Ethics approval and consent to participate}

Verbal consents were obtained from all the participants, because all the information was required from historic electronic records, and no any identified information is showed in the article and supplementary materials, which was approved by the Ethics Committee of Sichuan University West China Hospital. The study conforms to the Declaration of Helsinki.

\section{Consent for publication}

Not applicable

\section{Competing interests}

The authors declare that they have no competing interests.

\section{Publisher's Note}

Springer Nature remains neutral with regard to jurisdictional claims in published maps and institutional affiliations.

\section{Author details}

${ }^{1}$ Department of Pediatric Surgery, West China Hospital, Sichuan University, No. 37 of Guoxue Xiang, Chengdu 610041, China. ${ }^{2}$ Department of Urology, Institute of Urology, West China Hospital, Sichuan University, Chengdu, China. ${ }^{3}$ Department of Urology, Fujian Provincial Hospital, Fuzhou, China. ${ }^{4}$ Department of Urology, the Third Affiliated Hospital, Sun Yat-sen University, Guangzhou, China.
Received: 2 March 2018 Accepted: 28 November 2018

Published online: 06 December 2018

\section{References}

1. Wein AJ, Kavouss LR, Partin AW, Novick AC, Peters CA: CAMPBELL-WALSH Urology, 10th Edition. Saunders 2012.

2. Dall'Oglio MF, Ribeiro-Filho LA, Antunes AA, Crippa A, Nesrallah L, Goncalves $P D$, Leite KR, Srougi M. Microvascular tumor invasion, tumor size and Fuhrman grade: a pathological triad for prognostic evaluation of renal cell carcinoma. J Urol. 2007;178(2):425-8 discussion 428.

3. Goncalves PD, Srougi M, Dall'lio MF, Leite KR, Ortiz V, Hering F. Low clinical stage renal cell carcinoma: relevance of microvascular tumor invasion as a prognostic parameter. J Urol. 2004;172(2):470-4.

4. Rabjerg M. Identification and validation of novel prognostic markers in renal cell carcinoma. Dan Med J. 2017:64(10):B5339.

5. Ha YS, Chung JW, Chun SY, Choi SH, Lee JN, Kim BS, Kim HT, Kim TH, Byun SS, Hwang EC, et al. Impact of preoperative thrombocytosis on prognosis after surgical treatment in pathological T1 and T2 renal cell carcinoma: results of a multi-institutional comprehensive study. Oncotarget. 2017:8(38): 64449-58.

6. Errarte P, Beitia M, Perez I, Manterola L, Lawrie CH, Solano-Iturri JD, CalveteCandenas J, Unda M, Lopez Jl, Larrinaga G. Expression and activity of angiotensin-regulating enzymes is associated with prognostic outcome in clear cell renal cell carcinoma patients. PLoS One. 2017;12(8):e0181711.

7. Cai W, Zhong H, Kong W, Dong B, Chen Y, Zhou L, Xue W, Huang Y, Zhang $J$, Huang J. Significance of preoperative prognostic nutrition index as prognostic predictors in patients with metastatic renal cell carcinoma with tyrosine kinase inhibitors as first-line target therapy. Int Urol Nephrol. 2017; 49(11):1955-63.

8. Tsujita E, Ikeda Y, Kinjo N, Yamashita Yl, Hisano T, Furukawa M, Taguchi Kl, Morita M, Toh Y, Okamura T. Postoperative neutrophil-to-lymphocyte ratio as a predictor of long-term prognosis after pancreatectomy for pancreatic carcinoma: a retrospective analysis. Am Surg. 2017:83(6):610-6.

9. Jang WS, Cho KS, Kim MS, Yoon CY, Kang DH, Kang YJ, Jeong WS, Ham WS, Choi YD. The prognostic significance of postoperative neutrophil-tolymphocyte ratio after radical prostatectomy for localized prostate cancer. Oncotarget. 2017:8(7):11778-87.

10. Kang $\mathrm{M}$, Jeong $\mathrm{CW}$, Kwak $\mathrm{C}, \mathrm{Kim} \mathrm{HH}, \mathrm{Ku} \mathrm{JH}$. The prognostic significance of the early postoperative neutrophil-to-lymphocyte ratio in patients with urothelial carcinoma of the bladder undergoing radical cystectomy. Ann Surg Oncol. 2016;23(1):335-42.

11. Nazha B, Moussaly E, Zaarour M, Weerasinghe C, Azab B. Hypoalbuminemia in colorectal cancer prognosis: nutritional marker or inflammatory surrogate? World J Gastrointest Surg. 2015;7(12):370-7.

12. Critselis E, Panagiotakos DB, Machairas A, Zampelas A, Critselis AN, Polychronopoulos E. Postoperative hypoproteinemia in cancer patients following extensive abdominal surgery despite parenteral nutritional support. Nutr Cancer. 2011;63(7):1021-8.

13. Manning RD Jr. Effects of hypoproteinemia on renal hemodynamics, arterial pressure, and fluid volume. Am J Phys. 1987;252(1 Pt 2):F91-8.

14. Sang BH, Bang JY, Song JG, Hwang GS. Hypoalbuminemia within two postoperative days is an independent risk factor for acute kidney injury following living donor liver transplantation: a propensity score analysis of 998 consecutive patients. Crit Care Med. 2015:43(12):2552-61.

15. Shao M, Wang S, Parameswaran PK. Hypoalbuminemia: a risk factor for acute kidney injury development and progression to chronic kidney disease in critically ill patients. Int Urol Nephrol. 2017;49(2):295-302.

16. Zhang T, Deng Y, He P, He Z, Wang X. Effects of mild hypoalbuminemia on the pharmacokinetics and pharmacodynamics of dexmedetomidine in patients after major abdominal or thoracic surgery. J Clin Anesth. 2015;27(8): 632-7.

17. Miwa A, Morioka I, Hisamatsu C, Fujioka K, Morikawa S, Shibata A, Yasufuku M, Yokoyama N, Matsuo M. Hypoalbuminemia following abdominal surgery leads to high serum unbound bilirubin concentrations in newborns soon after birth. Neonatology. 2011;99(3):202-7.

18. Sullivan SA, Van Le L, Liberty AL, Soper JT, Barber EL. Association between hypoalbuminemia and surgical site infection in vulvar cancers. Gynecol Oncol. 2016:142(3):435-9.

19. Lee Jl, Kwon M, Roh JL, Choi JW, Choi SH, Nam SY, Kim SY. Postoperative hypoalbuminemia as a risk factor for surgical site infection after oral cancer surgery. Oral Dis. 2015;21(2):178-84. 
20. Critselis E, Panagiotakos DB, Machairas A, Zampelas A, Critselis AN, Polychronopoulos E. Risk and predictive factors of hypoalbuminemia in cancer patients following extensive abdominal surgery despite total parenteral nutritional support. Int J Food Sci Nutr. 2012;63(2):208-15

21. Crumley AB, Stuart RC, McKernan M, McMillan DC. Is hypoalbuminemia an independent prognostic factor in patients with gastric cancer? World J Surg. 2010;34(10):2393-8.

22. McMillan DC, Watson WS, O'Gorman P, Preston T, Scott HR, McArdle CS. Albumin concentrations are primarily determined by the body cell mass and the systemic inflammatory response in cancer patients with weight loss. Nutr Cancer. 2001;39(2):210-3.

23. Cai W, Zhang J, Chen Y, Kong W, Huang Y, Huang J, Zhou L. Association of post-treatment hypoalbuminemia and survival in Chinese patients with metastatic renal cell carcinoma. Chin J Cancer. 2017;36(1):47.

24. NCCN: NCCN clinical practice guidelines in oncology, kidney Cancer (version 2. 2017). https://www.nccn.org/professionals/physician_gls/default. aspx\#kidney.

25. KANG L, Jia H, Shibao Y, Jun M. Medical statistics, 6th edition: People's medical publishing house. 2013.

26. Shum CF, Bahler CD, Sundaram CP. Matched comparison between partial nephrectomy and radical nephrectomy for T2 NO MO tumors, a study based on the National Cancer Database. J Endourol. 2017:31(8):800-5.

27. Kunath F, Schmidt S, Krabbe LM, Miernik A, Dahm P, Cleves A, Walther M, Kroeger N. Partial nephrectomy versus radical nephrectomy for clinical localised renal masses. Cochrane Database Syst Rev. 2017;5:Cd012045.

28. Demir O, Bozkurt O, Celik S, Comez K, Aslan G, Mungan U, Celebi I, Esen A. Partial nephrectomy vs. radical nephrectomy for stage I renal cell carcinoma in the presence of predisposing systemic diseases for chronic kidney disease. Kaohsiung J Med Sci. 2017;33(7):339-43.

29. Tsukamoto T, Kumamoto Y, Miyao N, Yamazaki K, Takahashi A, Satoh M. Regional lymph node metastasis in renal cell carcinoma: incidence, distribution and its relation to other pathological findings. Eur Urol. 1990; 18(2):88-93.

30. Cheigh JS, Kim H, Stenzel KH, Tapia L, Sullivan JF, Stubenbord W, Riggio RR, Rubin AL. Systemic lupus erythematosus in patients with end-stage renal disease: long-term follow-up on the prognosis of patients and the evolution of lupus activity. Am J Kidney Dis. 1990;16(3):189-95.

31. Ryan AM, Hearty A, Prichard RS, Cunningham A, Rowley SP, Reynolds JV. Association of hypoalbuminemia on the first postoperative day and complications following esophagectomy. J Gastrointes Surg. 2007;11(10): 1355-60.

Ready to submit your research? Choose BMC and benefit from:

- fast, convenient online submission

- thorough peer review by experienced researchers in your field

- rapid publication on acceptance

- support for research data, including large and complex data types

- gold Open Access which fosters wider collaboration and increased citations

- maximum visibility for your research: over $100 \mathrm{M}$ website views per year

At $\mathrm{BMC}$, research is always in progress.

Learn more biomedcentral.com/submissions 